Journal of Educational Science and Technology

Volume 6 Number 1 April 2020 page 92-98

p-ISSN:2460-1497 and e-ISSN: 2477-3840

DOI: https://doi.org/10.26858/est.v6i1.13020

\title{
A Need Analysis of e-Kompas Specialization Service Model for High School Student to Improve the Selection of Majors in Higher Education
}

\author{
Farida Aryani ${ }^{1}$, Muhammad Rais ${ }^{2}$, Hamdan Arfandy ${ }^{3}$ \\ ${ }^{1}$ Counseling Guidance, Universitas Negeri Makassar, Indonesia \\ Email: farida.aryani@unm.ac.id \\ ${ }^{2}$ Education of Agricultural Technology, Universitas Negeri Makassar, Indonesia \\ Email: m.rais@unm.ac.id \\ ${ }^{3}$ Information and Technology, Universitas Negeri Makassar, Indonesia \\ Email: hamdanarfandy@gmail.com
}

(Received: January-2020; Reviewed: February-2020; Accepted: April-2020;

Avalaibel Online: April 2020; Published: April-2020)

This is an open access article distributed under the Creative Commons Attribution License

CC-BY-NC-4.0 @2019 by author (https://creativecommons.org/licenses/by-nc/4.0/ )

\begin{abstract}
This study aims to analyze the needs of specialization services for counselor in improving the insights of university selection using the future application of e-kompas. This research is a development research using Borg and Gall development model. This research activity focuses on need analysis activities. This research was conducted in Makassar city by involving counselor and high school student. The developed product is a future android based e-kompas application that begins with an in-depth analysis of service needs. Need analysis is done to counselor in Makassar City. The result of requirement analysis using counselor perception questionnaire about the specialization service for the selection of majors in the college for high school students shows that the counselors generally have difficulties in directing the selection of majors for high school students to continue college. Need analysis shows that counselors have a high desire to use e-kompas instrument based on android application that is practical and useful in directing high school students to choose majors in universities that match the talents, interests and potential of high school students.
\end{abstract}

Keywords: Specialization service; e-kompas; selection major

\section{INTRODUCTION}

The specialization services in the context of the 2013 curriculum is a part of the school counseling program. Concentration essentially implicitly contained in Law No. 20 of 2003 which is an advocacy effort and how to provide space to learners by considering the uniqueness of individuals in order to develop their potential, have a high spirituality, develop personality/character and skills needed by society and nation so as to obtain optimal development. Specialization is a process of making choices and decisions by learners in areas of expertise based on an understanding of the potential of self and opportunities (Kemendikbud, 2013). Therefore, counseling guidance strives to help learners understand themselves, recognize their surroundings, and make decisions and implement them responsibly (ILO, 2011 ; Lunenburg, 2010)

The phenomenon in the field shows that many students of senior high school grade 12 are confused in choosing a college that will be entered after school graduation. Graduates of senior high school have not been all based on their interests and competencies (Gysbers \& Henderson, 2012). Many students are wrong in 
choosing majors, and find many difficulties in learning (Jayawardena, Kraayenoord, \& Carroll, 2020). Also found many people who work not according to interests and skills that ultimately choose to get out of work. Most students tend to follow-up friends and follow their parents, not choosing a department based on their talents of interest and potential. According to the Integrity Development Flexibility (IDF) reports that 87 percent of Indonesian students choose the wrong majors. If this is allowed to happen to the younger generation, then what will happen is that many students will experience problems in their academic achievement on campus, after graduating students will be fail in their career and future, and of course unemployment rate will increase in Indonesia.

The future e-kompas service is a specialization service that is part of a high-school career counseling program that can help high school students recognize their talents, interests and potentials so they can make decisions in planning their future (choosing majors in college). In this case, career counseling program in high school is expected to help students to know theirself, accept theirself, direct, and take decisions. Counseling helps students to achieve their optimal development and independence in their lives, advanced education, and careers (Aryani \& Rais, 2017). Future e-kompas services help high school students, especially 12 th grade students to be able to choose the right majors in college.

Through the future e-kompas application and guidance of counselor, high school students can have an insight into the selection of majors in college. The insights of college selection are meant for information services in career counseling programs granted to high school students (Igbinedion \& Ojeaga, 2012 ; Aryani \& Rais, 2017): 1) self-knowledge, including individual relationships with characteristics and perceptions, and interpersonal and environmental relationships; 2) understanding of advanced education in universities and occupations as well as factors affecting constant change, including work attitudes and discipline; 3) an understanding of needs and many factors can be considered in career planning; and 4) decision making and planning for the future. The use of computer based applications must become an obligation of the counselor in helping students in the process of guidance and counseling services in the School. Jimmy \& Noel (Jimmy \& Noel, 2008) explains that the reality on the ground, the implementation of assessment in schools requires time and energy counselors are not small. Therefore, it is possible to use technological innovation, one of which is the computer as an assessment tool. At least by using computer assessment activities undertaken by counselors at the school becomes more fluent and efficient .

This research is expected to contribute in solving the nation's problems in the field of education, which is to help counselor in high school in specialization services in the curriculum in 2013 which has been still a conventional service. Future android based eKompas applications can facilitate counselor in providing services so that students can choose majors in college according to their talents, interests and potential. A preliminary review of this research as part of pre-development is a need analysis of specialization services for counselor in planning for the future and improving the selection of majors in universities.

\section{METHOD}

Research is a development study using the Borg and Gall development model (Borg \& Gall, 2003). Stages of development begins with a need assessment to find out the things that are needed related to the development of e-kompas based application model android. Research methods undertaken in this research focus on the needs analysis activities conducted by requesting teacher responses related to the needs of ekompas applications. For that, given a questionnaire to 20 counselors of high school in Makassar. The instrument used in this study is a questionnaire about the counselor perceptions of the specialization services for third graders of high school who will choose majors in college. The type of data used in this study is quantitative data.

\section{RESULTS AND DISCUSSION}

\section{Result}

The results of pre-development research are presented in the following results:

\section{Problems faced by teacher counselor}

The counselor response to the problems experienced in the school is shown in table 1 . Until now, the counselor still has difficulty in directing high school students in choosing the appropriate department basedon their academic talents and interests to continue college. The absence of valid and practical instruments towards the majors of high school students, 
further add to the difficulty of counselor in helping students find the majors that will be chosen in college. This happens especially in the 12th grade that will end school and will soon resume college.

Table 1. Problems faced by the related counselor

\begin{tabular}{|c|c|c|c|c|c|c|c|c|c|}
\hline No & Problems faced by counselors & $\mathbf{S A}$ & $\mathbf{A}$ & $\mathbf{D}$ & $\mathbf{S}$ & $\begin{array}{l}\% \\
\text { SA }\end{array}$ & $\begin{array}{l}\% \\
\text { A }\end{array}$ & $\begin{array}{l}\% \\
\text { D }\end{array}$ & $\%$ \\
\hline 1 & $\begin{array}{l}\text { I have difficulty in directing students in } \\
\text { college selection }\end{array}$ & 6 & 14 & 0 & 0 & 30 & 70 & 0 & 0 \\
\hline 2 & $\begin{array}{l}\text { I have difficulty in developing instruments } \\
\text { to measure student's interest in college } \\
\text { selection }\end{array}$ & 12 & 8 & 0 & 0 & 60 & 40 & 0 & 0 \\
\hline 3 & $\begin{array}{l}\text { I feel less informed about what majors are } \\
\text { in college }\end{array}$ & 15 & 5 & 0 & 0 & 75 & 25 & 0 & 0 \\
\hline 4 & $\begin{array}{l}\text { Sometimes I have difficulty in directing } \\
12 \text { th graders in college selection to college }\end{array}$ & 7 & 13 & 0 & 0 & 35 & 65 & 0 & 0 \\
\hline & Amount & 10 & 10 & & & 50 & 50 & & \\
\hline
\end{tabular}

Note: $\mathrm{SA}=$ Strongly Agree; $\mathrm{A}=$ Agree $; \mathrm{D}=$ Disagree; $\mathrm{S}=$ Strongly Disagree

The lack of information and socialization to schools related to the existing majors of higher education increases the level of difficulty of counselor in conveying information majors that exist in universities. Counselor responses that generally choose categories agree and strongly agree on these conditions provide confirmation that counselor need valid and practical applications in measuring the talents and interests of high school students. The application in on this study is an android based e-Kompas application. An application that makes it easly for counselor especially counselor in high school in helping students provide insights election majors in college. Therefore, it is necessary to measure counselor response to the importance of eKompas application based on android.

Table 2. The Importance of Selection of Departments in Universities Based on e-kompas Applications

\begin{tabular}{|c|c|c|c|c|c|c|c|c|c|c|}
\hline No & $\begin{array}{l}\text { The importance of e-kompas services } \\
\text { based on android }\end{array}$ & $\mathbf{S A}$ & $\mathbf{A}$ & D & $\mathbf{S}$ & $\begin{array}{r}\% \\
\text { SA }\end{array}$ & $\% \mathrm{~A}$ & \multicolumn{2}{|c|}{$\% \mathrm{D}$} & $\% \mathrm{~S}$ \\
\hline 1 & $\begin{array}{l}\text { I think career counseling service is } \\
\text { very important to be given to high } \\
\text { school students }\end{array}$ & 19 & 1 & 0 & 0 & 95 & 5 & \multicolumn{2}{|c|}{0} & 0 \\
\hline 2 & $\begin{array}{l}\text { I think career counseling services can } \\
\text { help high school students in choosing } \\
\text { majors in college }\end{array}$ & 20 & 0 & 0 & 0 & 100 & 0 & \multicolumn{2}{|c|}{0} & 0 \\
\hline 3 & $\begin{array}{l}\text { During this time I always provide } \\
\text { programmed career guidance services } \\
\text { in classes } 10,11 \text {, and } 12 \text { in senior high } \\
\text { school }\end{array}$ & 16 & 4 & 0 & 0 & 80 & 20 & \multicolumn{2}{|c|}{0} & 0 \\
\hline 4 & \multicolumn{2}{|c|}{$\begin{array}{l}\text { I think, we need an instrument in helping } \\
\text { students map students talents and interests to } \\
\text { help } 12 \text { th graders in college selection }\end{array}$} & 18 & 2 & 0 & 0 & 90 & 10 & 0 & 0 \\
\hline 5 & \multicolumn{2}{|c|}{$\begin{array}{l}\text { I think we need to develop an instrument } \\
\text { based on android application to help students } \\
\text { in the selection of majors in college }\end{array}$} & 18 & 2 & 0 & 0 & 90 & 10 & 0 & 0 \\
\hline 6 & \multicolumn{2}{|c|}{$\begin{array}{l}\text { I think with the development of career } \\
\text { application e-kompas is a very good } \\
\text { alternative in helping 12th graders senior high } \\
\text { school in the selection of majors in college }\end{array}$} & 19 & 1 & 0 & 0 & 95 & 5 & 0 & 0 \\
\hline
\end{tabular}


Note: $\mathrm{SA}=$ Strongly Agree; $\mathrm{A}=$ Agree; $\mathrm{D}=$ Disagree; $\mathrm{S}=$ Strongly

The counselor response to the use of ekompas application for the selection of majors for senior high school students who will continue college at university shows a high desire. The unavailability of valid and practical application of majors by utilizing android applications has encouraged a positive response of counselor to use applications that can help map the talents and interests of students, especially the 12th grade who will continue studying in college. Generally counselor need electronic based career applications as an alternative instrument in the selection of majors in college because it is very easy, fast and accurate in its use.

The percentage of indicators of counselor attitudes and responses to future e-kompas applications that include: 1) problems faced by counselor in the majors and 2) the importance of application-based e-kompas majors can be presented in three indicators are high, medium, and low. The analysis results are presented in the following diagram:

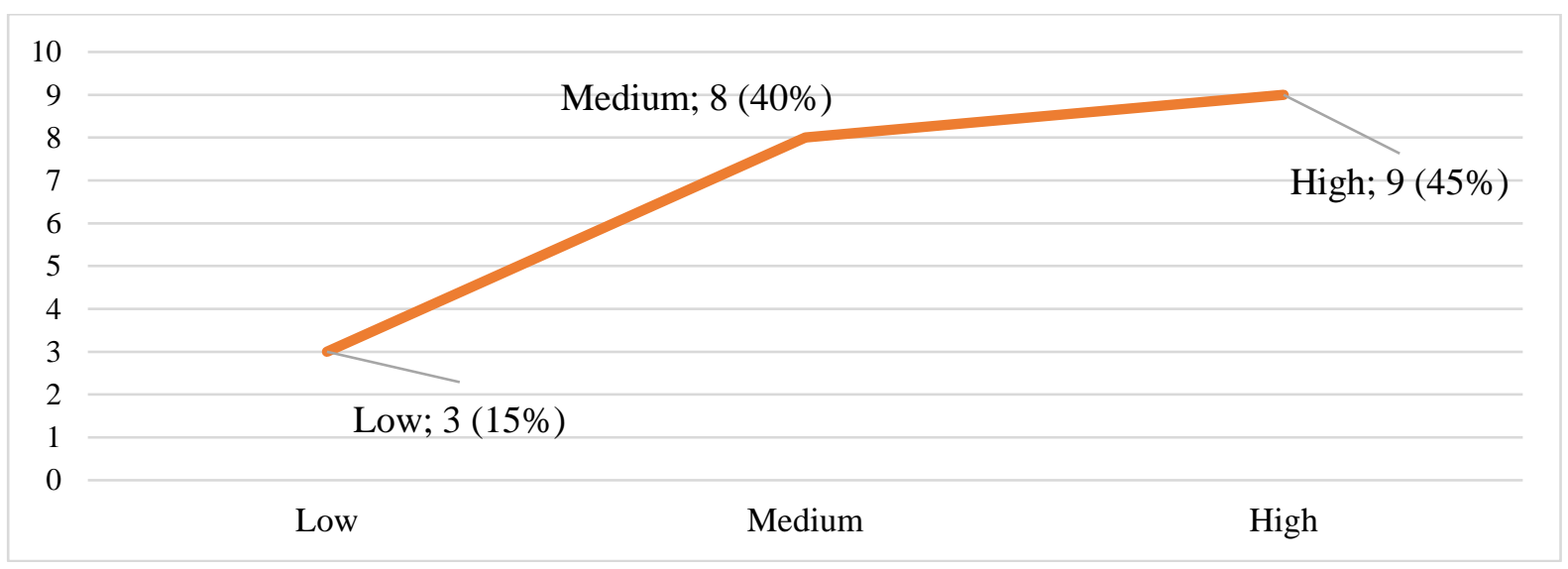

Figure 1. The level of problems faced by the counselor related to senior high school

Based on the picture above, the problem of obscurity faced by the counselor related to senior high school students to choose the majors in college is high 9 (45\%). The high problems felt by counselor due to the lack of information on majors services for high school students to choose the majors in accordance with their talents and interests continue college in college.
If analyzed further regarding the importance of e-kompas services based on android for majors for senior high school students, counselor shows strong desire and hope for the development of e-kompas application based on android to assist students in the selection of majors in universities. Description of needs analysis is shown in the following graph figure 2:

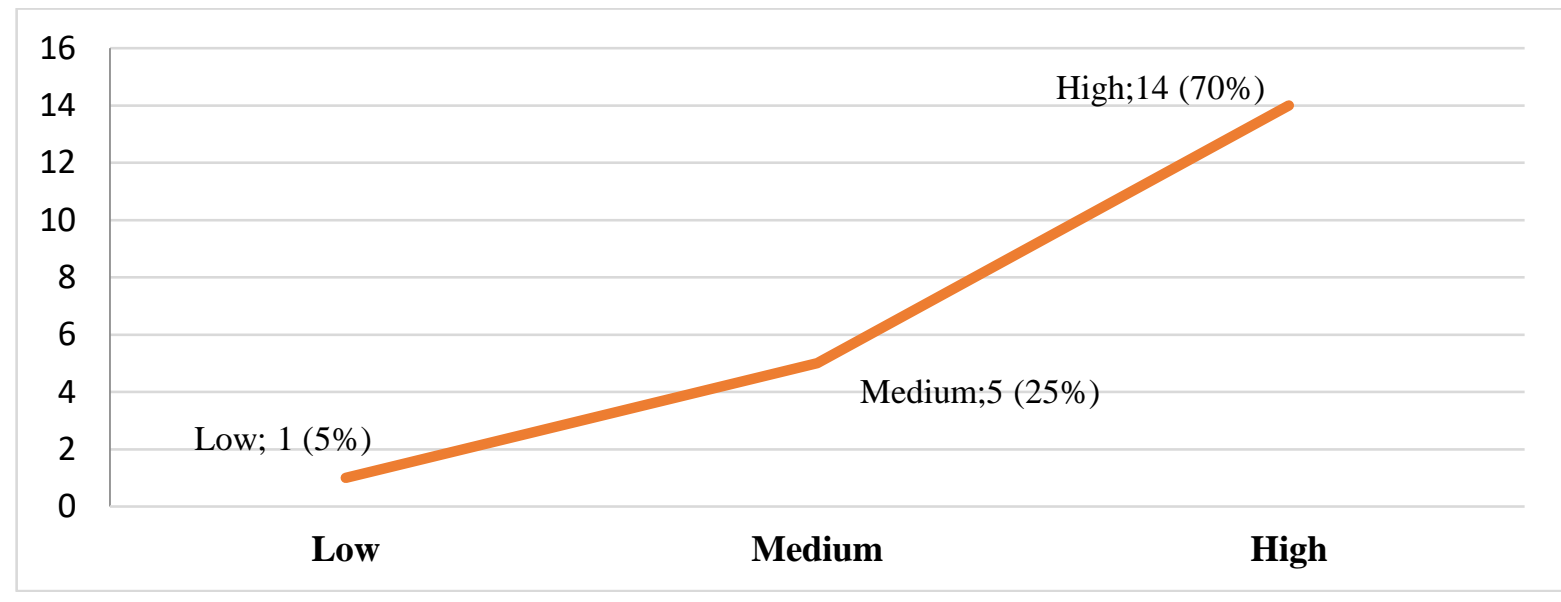

Figure 2. The importance of e-kompas services based on android 
In Figure 2, it can be explained that counselor consider the importance of using ekompas application as an alternative in choosing a major in college. The e-kompas application that will be developed in this research is an android based application, considering that information technology based on mobile application is growing rapidly. With the development of ekompas application can help the counselor in providing ICT based career guidance services. In other words, the development of e-kompas application is used as a specialization assessment service for 12th grade high school students in order to continue their education in universities according to their talents, interests and potentials of students.

\section{Discussion}

Specialization services as part of the academic and career field. The tutoring service is aimed to achiev optimal academic adjustments that take into account individual student differences in both talent, interest and other potential aspects. While career counseling services (Mihaela \& Cristina, 2015) aims to assist students in recognizing and developing their career potential in accordance with the talents, interests and other abilities so that learners can be independent and able to make the right decision. In other words, this career counseling service is intended to provide the widest possible opportunity for students to develop their potential, talents, interests based on individual differences. The results showed that interest is closely related to learning achievement (Kpolovie, 2014). This means that if child has a high interest in a particular subject, it will increase his or her achievement motivation and will certainly affect his future success (ACT, 2008).

During this service specialization has been done in high school, especially in directing the majors of class $\mathrm{X}$ students as required in the curriculum 2013. The results showed that application-based android SIMPESA is valid and practical to use and it can increase student self confidence in student selection in class X in SMA (Aryani \& Rais, 2017). The next problem is how with the students of class XII, how to develop a specialization service that can help grade XII high school students to be able to choose the majors in the college? Therefore, further research is to develop application of e-kompas based on android which is intended for high school students of XII class that can assist them in choosing majors in college according to their talents, interests and potentials.

The result of requirement analysis above shows that during this time high school teachers especially in class XII have difficulties in providing career guidance service especially faced with confused student problem in continuing their study in college. So far, career guidance services provided in class XII only focus on information services in universities only and there is no specialization service that can map the talents, interests and potential of students so that it can take decisions for further study in college. The results of the Creed, Patton, and Prideaux studies in found that $50 \%$ students were confused in decision-making to further college. One of the factors is that there are so many choices of education and types of jobs available. Limited information on various jobs that exist in the community, of course, make students to think or choose according to what is known so that there was misunderstanding of students in choosing the department. There are approximately $35 \%$ of students who experience difficulties, confusion, and skepticism in determining the choice of further study, including on which majors and colleges will be his choice (Creed \& Prideaux, 2006).

Furthermore, the results of the needs analysis also show that to facilitate the counselor in career guidance services, especially in class XII SMA needs to be developed android based ekompas application as an instrument that can measure talent, interest and potential students in the selection of majors in universities. So far there is no instrument that measures it. So far in the activities of career counseling services in high schools done conventionally, and consequently counselor often have difficulty in collecting student data (Emmanuel A.K \& V.R., 2015). Counselor in schools in providing services that encourage students are demanded not only have academic competence and professional competence in the field of guidance and counseling, but more specifically able to use and develop career guidance media, especially based on ICT (Information and Communication Technology) and master the theoretical repertoire and procedural including technology in guidance and counseling (Jimmy \& Noel, 2008). Therefore the result of this requirement analysis indicates that the need to develop application of e-based andoid d e-kompas which can help the counselor in mapping the students according to their talents, interests and potential so that students can 
independently in planning and taking the best decision in

\section{CONCLUSION AND SUGGESTION}

The result of this study shows that many counselors who have difficulties in charting and directing students of class XII SMA in college selection in college. There is no tool or instrument that can help students in measuring talents, interests and potential students in the selection of majors in college. In addition, the results of research shows that counselor stated the need to use the application in directing and increasing the selection of majors for high school students who will study in college. This application for the counselor in high school helps them to direct the students to map their academic talents and interests according to the chosen majors in the college. Therefore, with the development of e-application based android applications can help students in the selection of majors in universities in accordance with the talents, interests and potential of high school students.

\section{ACKNOWLEDGEMENT}

Further thanks to: Directorate General of Higher Education that funded this study and lecturer and teacher who participated on this study.

\section{REFERENCES}

ACT. (2008). The Path to Career Success: High School Achievement, Certainty of Career Choice, and College Readiness Make a Difference. Lowa City: Educational Issues.

Aryani, F., \& Rais, M. (2017). Model EPeminatan: Solusi Praktis Merencanakan Karier Masa Depan. Makassar: Badan Penerbit UNM.

Borg, W. R., \& Gall, M. D. (2003). Educational Research: an Introduction (7. ed). . New York: Logman Inc.

Creed, P. a., \& Prideaux, L. A. (2006). Causal Relationship Between Career Indecision and Career DecisionMaking Self-Efficacy: A Longitudinal Cross-Lagged Analysis. Journal of Career Development, 33(1), 47-65.
Emmanuel A.K, E. S., \& V.R., M. (2015). Ecounseling implementation: Students' life stories and counseling technologies in persperctive. International journal of education and development using information and communication technology (IJEDICT), 10(3), 32-48.

Gysbers, N. C., \& Henderson, P. (2012). Developing \& managing your school guidance \& counseling program, 5th ed. America: American Counseling Association.

Igbinedion, V., \& Ojeaga, I. (2012). Use of Career Education and Occupation Information Services in Boosting Enrolment into Vocational and Technical Education Programs in Nigeria. International Education Studies, 5(4), 20-29.

ILO. (2011). Panduan Bimbingan Karir. Jakarta: ILO.

Jayawardena, P. R., Kraayenoord, C. E., \& Carroll, A. (2020). Factors that influence senior secondary school students' science learning. International Journal of Educational Research, 100, 101523.

Jimmy, T., \& Noel, M. L. (2008). Teachers' Perspectives on the Iintegration of Information and Communication Techonologies (ICT) in School Counseling. International Journal of Education and Development Using Information and Communication Techonology (IJEDICT, 35-49.

Kemendikbud. (2013). Pedoman Peminatan Peserta Didik. Jakarta.

Kpolovie, P. (2014). Academic Achievement Prediction: Role of Interest in Learning and Attitude towards School. International Journal of Humanities Social Sciences and Education (IJHSSE), 1(11), 73-100.

Lunenburg, F. (2010). Scholl Guidance and Counseling Services. Schooling, 1(1), 10-21.

Mihaela, N., \& Cristina, I. G. (2015). A Research on The Educational Counseling and 
Aryani, Rais, Arfandy. A Need Analysis of e-Kompas... | 98

Career Guidance in Romania.

EuropeanScientific Journal, 2. 